\title{
Effect of aqueous extract of African mistletoe (Tapinanthus bangwesis) on some serum enzymes of rats with carbon tetrachloride-induced liver damage
}

\author{
Stephen I. OMEODU, Michael O. MONANU * and Emmanuel O. ANOSIKE \\ Department of Biochemistry, University of Port Harcourt, PMB 5323 Port Harcourt, Nigeria. \\ Corresponding authors E-mail: mikemonanu@yahoo.com, Phone: 234-08033122573
}

\begin{abstract}
The in vivo effects of aqueous extract of African mistletoe (Tapinanthus bangwesis) on the serum levels of aspartate and alanine amino transferases (AST and ALT) and alkaline phosphatase (ALP) of Wistar albino rats with carbon tetrachloride-induced liver damage were investigated. The extract was orally administered at $12.5,25.0$ and $37.5 \mathrm{mg} / \mathrm{kg}$ body weight 24 hours and every subsequent 48 hours following carbon tetrachloride $\left(\mathrm{CCl}_{4}\right)$ administration with vegetable oil carrier $(1: 1)$ at a dose of $0.5 \mathrm{mg} / \mathrm{kg}$ body wt. This study was for three weeks. The results indicated that the serum levels of AST, ALT and ALP reduced significantly $(\mathrm{p}<0.05)$ at the 14-day period in rats given the varying doses of the extract when compared to the levels obtained for $\mathrm{CCl}_{4}$ treated rats. While the serum levels of these enzyme activities also decreased for $\mathrm{CCl}_{4}$-control rats during the period of study, the reductions were more with rats given the aqueous extracts after $\mathrm{CCl}_{4}$ administration, almost approaching the control levels. However, the effects were not dose-dependent. The results of histopathology of the liver samples were consistent to some extent with the enzyme levels obtained. The liver architecture following $\mathrm{CCl}_{4}$ administration improved at $12.5 \mathrm{mg} / \mathrm{kg}$ body weight of extract through the period investigated. Similar patterns were seen at 25.0 and $37.5 \mathrm{mg} / \mathrm{kg}$ body weight of the extract. The findings in this study suggest that the aqueous extract of African mistletoe (T. bangwesis) may have beneficial actions to challenged liver by assisting with repair of hepatic damage.

(C) 2008 International Formulae Group. All rights reserved.
\end{abstract}

Keywords: aqueous extracts, hepatic damage, histopathology, enzyme activity.

\section{INTRODUCTION}

Plant extracts have continued to play significant roles in human health care particularly in developing countries as over $80 \%$ of the world population had been shown to rely on traditional medicine as source of health care. These practices depend on plant materials (WHO, 1993). Studies over the years by many scientists have shown promising returns for application of numerous plants materials (roots, barks and leaves) either whole or as extracts in the treatment of various ailments. The active ingredients point to the phytochemicals present in the plant materials (El-Said et al, 1971; Sofowara and Isaacs-Sodey, 1971; Sofowara, 1975; Ekeke and Shode, 1990; Gupta, 1994; Michel, 2002; Elekwa et al., 2005, Wang et al., 2007).
It had been shown that even single administration of carbon tetrachloride $\left(\mathrm{CCl}_{4}\right)$, a hepatotoxin, could produce damages to the liver of experimental animals (Anand et al., 1992). The suggested mechanism for this damage included lipid peroxidation and the covalent binding of $\mathrm{CCl}_{4}$ reactive metabolites to lipids and proteins (Faber and Gerson, 1984; Masuda and Nakamura, 1990). Aspartate and alanine amino transferases in addition to alkaline phosphatase have been established as marker enzymes for the liver and variations in the serum/plasma levels of these enzymes give indications of the 'health' of the liver of the individual/experimental animal (Sturgill and Lambert, 1992).

African mistletoe ( $T$. bangwesis) is the common genera of the hemi-parasitic 
angiosperm (flowering plant) found in West Africa and belongs to the Loranthaceae family (Onofegahara, 1971). Several medicinal applications have been ascribed to extracts of this plant including anti-diabetic (Obatomi et al., 1994), immune modulation (Stein and Berg, 1998), proliferation of haematopoietic progenitor cells (Vehemeyer et al., 1998) and anti-neoplastic activities (Anthony et al., 1997). There had been reports of protective effects of extracts from some plant extracts against $\mathrm{CCl}_{4}$-induced liver damage (Dahiru et al., 2005; Obi et al., 2005). The present report addresses the possible effects of aqueous extract of African mistletoe (T. bangwesis) on the serum levels of aspartate and alanine amino transferase, and alkaline phosphatase activities of Wistar albino rats following hepatic damage by administration of $\mathrm{CCl}_{4}$. The objective was to investigate if the extracts could offer recovery of the damaged liver of the experimental animal, thus offering therapeutic application for the extract of African mistletoe.

\section{MATERIALS AND METHODS \\ Preparation of Plant extract}

The mistletoe was obtained from Rumualogu, a village near University of Port Harcourt, Nigeria, where it was found growing on a bitter orange. It was properly identified at the Plant and Biotechnology Centre of the University of Port Harcourt, with University of Port Harcourt Herbarium number as 481 (Collector's number 001). The leaves were carefully plucked, thoroughly washed and air dried. The dried leaves were ground with a ceramic pestle and mortar. The ground sample was dried in an electric oven at $108{ }^{\circ} \mathrm{C}$ for $1 \mathrm{hr}$. A $50 \mathrm{~g}$ portion was transferred into a measuring cylinder and 300 $\mathrm{ml}$ of distilled water added. After vigorous shaking for 10 minutes, it was made up to 500 $\mathrm{ml}$ with distilled water and allowed to stand for $24 \mathrm{hrs}$. The mixture was then filtered thrice, each time through a piece of white cotton cloth. A final filtration using Whatman No. 541 filter paper followed and the filtrate was evaporated using rotary evaporator. The residue was then dissolved in distilled water to a known concentration and stored in the refrigerator until use (within 48 hours).

\section{Carbon-tetrachloride $\left(\mathrm{CCl}_{4}\right)$ treatment}

Liver damage was induced by the oral administration of $\mathrm{CCl}_{4}$ diluted with vegetable oil (1:1) at $0.5 \mathrm{mg} / \mathrm{kg}$ body wt except for the control animals (no liver damage) (Rao and Misra, 1998).

\section{Animals}

A total of seventy eight (78) male Wistar albino rats (4-5 weeks old), weighing 185-220 g were obtained from the Department of Biochemistry, University of Port Harcourt animal house. They were housed in stainless steel cages (4 rats per cage) and kept in a well-ventilated room. The rats were fed with standard diet (Livestock Feeds Nig. Ltd, Ikeja, Nigeria) and water ad libitum. The standard guidelines for the use of experimental animals (including applying humane actions during sacrifice) were adhered to.

\section{Effect of extracts}

The rats were divided into five groups. At the end of two days following grouping to allow the rats get used to their new caging situation, $0.5 \mathrm{ml} / \mathrm{kg}$ body wt of $\mathrm{CCl}_{4}$ was orally administered to the rats in groups 2, 3, 4 and 5 (group 1 was the control i.e. no liver damage). After a 24-hr wait, 12.5, 25.0 and $37.5 \mathrm{mg} / \mathrm{kg}$ body wt of the extract were administered to groups 3, 4 and 5, respectively, on a 24-hourly dosage for three weeks.

For analysis, four (4) rats from each group were sacrificed at determined time intervals (24-hr for control and $\mathrm{CCl}_{4}$-treated rats, and 1-, 2-, 3-week for all groups) after anesthetics with chloroform. Fresh blood was drawn by cardiac puncture and serum obtained. For histopathology, fresh livers obtained from the sacrificed rats were immediately placed in $10 \%$ formaldehyde.

\section{Enzyme assays}

The determination of aspartate amino transferase in the serum samples were performed at $37{ }^{\circ} \mathrm{C}$ using the Randox kit by measuring the amount of oxaloacetate hydrazone formed in the presence of Laspartate, $\alpha$-oxoglutarate and 2,4-dinitro phenyl hydrazine as reported by Ibekwe et al. (2007). For alanine amino transferase, Lalanine replaced L-aspartate. The determination of alkaline phosphatase activity used the Diagnosticum Rt kit and monitored 
the amount of inorganic phosphate released from p-nitro phenyl phosphate following the procedure of Haussament (1977).

\section{Histopathology}

Thin sections of the preserved liver slices obtained with the use a tissue slicer were fixed on microscopic slides and stained before observing under the microscope following the method described by Baker and Silverton (1985).

\section{Statistical analysis}

All data were expressed as mean \pm SEM and statistically analyzed with the student's t-test at $95 \%$ confidence level. A p value of $<0.05$ was considered statistically significant.

\section{RESULTS}

The results obtained for the serum enzyme level of aspartate amino transferase are shown in Table 1. The enzyme level following administration of $\mathrm{CCl}_{4}$ was higher for group 2 than group 1 (the control), starting 24 hours post-administration and remained higher even after 21 days. Tables 2 and 3 show the results for serum alanine amino transferase and alkaline phospatase, respectively. Both showed similar patterns with the results in Table 1.

The aqueous extract, at $12.5 \mathrm{mg} / \mathrm{kg}$ body weight progressively exhibited significant reduction $(\mathrm{p}<0.05)$ in the levels of the three enzyme activities in the course of the experimental period, approaching the control values. Similar effect was seen for 25.0 and $37.5 \mathrm{mg} / \mathrm{kg}$ body weight. However, the effects were not dose-dependent as the reductions did not show linear relationship with dose of extract.

The results of the histological examination of the livers of the experimental animals are shown by representative photographs (Figures 1, 2, $3 \& 4$ ) as well as the summary in Table 4 . The normal liver

Table 1: Serum aspartate amino transferase (AST) activity (U/l) in rats following $\mathrm{CCl}_{4}$-induced liver damage and administration of aqueous extract of $T$. bangwesis.

\begin{tabular}{lcccc}
\hline Treatment & $\begin{array}{c}\text { 24hrs post } \\
\mathbf{C C l}_{\mathbf{4}}\end{array}$ & $\begin{array}{c}\text { 7-days post } \\
\mathbf{C C l}_{\mathbf{4}}\end{array}$ & $\begin{array}{c}\text { 14-days post } \\
\mathbf{C C l}_{\mathbf{4}}\end{array}$ & $\begin{array}{c}\text { 21-days post } \\
\mathbf{C C l}_{\mathbf{4}}\end{array}$ \\
\hline Group 1(control) & $115.64+2.54$ & $117.42+2.99$ & $116.35+1.25$ & $118.43+3.01$ \\
Group 2 (CCl4) & $209.32+3.72^{*}$ & $182.37+3.00^{*}$ & $163.47+22.89^{*}$ & $130.40+22.09^{*}$ \\
Group 3 (12.5 mg) & $\mathrm{ND}$ & $165.71+3.21^{\mathrm{y}}$ & $144.49+2.98^{\mathrm{y}}$ & $125.48+2.43^{\mathrm{y}}$ \\
Group 4 (25.0 mg) & $\mathrm{ND}$ & $151.95+2.87^{\mathrm{y}}$ & $139.49+2.50^{\mathrm{y}}$ & $121.48+2.79^{\mathrm{y}}$ \\
Group 5 (37.5 mg) & $\mathrm{ND}$ & $144.48+2.79^{\mathrm{y}}$ & $130.42+3.01^{\mathrm{y}}$ & $119.28+2.45$ \\
\hline
\end{tabular}

Values in the column with superscript * are significantly different $(\mathrm{p}<0.05)$ from the control (Group 1) while superscript $\mathrm{y}$ denotes values significantly different $(\mathrm{p}<0.05)$ from the control (Group 1) and Group 2 (CCl4-treated); ND: not determined. Triplicate determinations for 4 rats per group.

Table 2: Serum alanine amino transferase (ALT) activity (U/l) in rats following $\mathrm{CCl}_{4}$-induced liver damage and administration of aqueous extract of $T$. bangwesis.

\begin{tabular}{lcccc}
\hline Treatment & $\begin{array}{c}\mathbf{2 4} \mathbf{~ h r s ~ p o s t} \\
\mathbf{C C l}_{\mathbf{4}}\end{array}$ & $\begin{array}{c}\text { 7-days post } \\
\mathbf{C C l}_{\mathbf{4}}\end{array}$ & $\begin{array}{c}\text { 14-days post } \\
\mathbf{C C l}_{\mathbf{4}}\end{array}$ & $\begin{array}{c}\mathbf{2 1 - d a y s ~ p o s t} \\
\mathbf{C C l}_{\mathbf{4}}\end{array}$ \\
\hline Group 1(control) & $38.47 \pm 0.95$ & $39.37 \pm 1.00$ & $38.79 \pm 0.97$ & $38.65 \pm 0.99$ \\
Group 2(CCl $)$ & $104.27 \pm 1.45^{*}$ & $94.81 \pm 1.79^{*}$ & $83.37 \pm 2.00^{*}$ & $79.48 \pm 2.01^{*}$ \\
Group 3(12.5 mg) & $\mathrm{ND}$ & $84.79 \pm 1.99^{\mathrm{y}}$ & $78.27 \pm 1.85^{\mathrm{y}}$ & $69.25 \pm 1.99^{\mathrm{y}}$ \\
Group 4(25.0 mg) & $\mathrm{ND}$ & $78.87 \pm 2.00^{\mathrm{y}}$ & $67.40 \pm 2.98^{\mathrm{y}}$ & $48.98 \pm 262^{\mathrm{y}}$ \\
Group 5(37.5 mg) & $\mathrm{ND}$ & $52.17 \pm 2.01^{\mathrm{y}}$ & $48.78 \pm 2.00^{\mathrm{y}}$ & $40.99 \pm 1.48$
\end{tabular}

Values in the columns with superscript * are significantly different $(\mathrm{p}<0.05)$ from the control (Group 1) while superscript $\mathrm{y}$ denotes values significantly different $(\mathrm{p}<0.05)$ from the control (Group 1) and Group 2 ( $\mathrm{CCl}_{4}$-treated); ND: not determined. Triplicate determinations for 4 rats per group. 
Table 3: Serum alkaline phosphatase (ALP) activity (U/l) in rats following $\mathrm{CCl}_{4}$-induced liver damage and administration of aqueous extract of T. bangwesis.

\begin{tabular}{lclll}
\hline Treatment & $\begin{array}{c}\mathbf{2 4} \mathbf{~ h r s ~ p o s t} \\
\mathbf{C C l}_{\mathbf{4}}\end{array}$ & $\begin{array}{c}\text { 7-days post } \\
\mathbf{C C l}_{\mathbf{4}}\end{array}$ & $\begin{array}{c}\text { 14-days post } \\
\mathbf{C C l}_{\mathbf{4}}\end{array}$ & $\begin{array}{c}\text { 21-days post } \\
\mathbf{C C l}_{\mathbf{4}}\end{array}$ \\
\hline Group 1 (control) & $187.48 \pm 5.21$ & $189.40 \pm 4.50$ & $188.80 \pm 4.55$ & $187.99 \pm 4.87$ \\
Group 2 $\left(\mathrm{CCl}_{4}\right)$ & $402.93 \pm 8.42^{*}$ & $394.49 \pm 8.99^{*}$ & $362.00 \pm 9.00^{*}$ & $340.91 \pm 8.96^{*}$ \\
Group 3 $(12.5 \mathrm{mg})$ & $\mathrm{ND}$ & $367.88 \pm 9.10^{\mathrm{y}}$ & $320.77 \pm 8.95^{\mathrm{y}}$ & $299.78 \pm 9.45^{\mathrm{y}}$ \\
Group 4 $(25.0 \mathrm{mg})$ & $\mathrm{ND}$ & $340.75 \pm 7.98^{\mathrm{y}}$ & $310.71 \pm 9.02^{\mathrm{y}}$ & $240.02 \pm 9.87^{\mathrm{y}}$ \\
Group 5 $(37.5 \mathrm{mg})$ & $\mathrm{ND}$ & $300.47 \pm 7.98^{\mathrm{y}}$ & $270.78 \pm 8.15^{\mathrm{y}}$ & $220.50 \pm 8.01^{\mathrm{y}}$ \\
\hline
\end{tabular}

Values in the columns with * are significantly different $(\mathrm{p}<0.05)$ from the control (Group 1) while superscript y denoted values significantly different $(\mathrm{p}<0.05)$ from the control (Group 1) and Group $2\left(\mathrm{CCl}_{4}\right.$-treated); ND: not determined. Triplicate determinations for 4 rats per group.

Table 4: Summary of the histological examination of the liver architecture of experimental animals.

\begin{tabular}{|c|c|c|c|}
\hline Group & Treatment & $\begin{array}{l}\text { Period of } \\
\text { examination }\end{array}$ & Description of effects \\
\hline 1. & Norman feed (control) & $24 \mathrm{hrs}$ & Normal liver architecture \\
\hline 2. & Feed $+\mathrm{CCl}_{4}$ & $24 \mathrm{hrs}$ & $\begin{array}{l}\text { Distorted liver architecture with congestion } \\
\text { of sinusoids and central veins. Hepatocytes } \\
\text { distended with vacuolar degeneration }\end{array}$ \\
\hline 3. & $\begin{array}{l}\text { Feed }+\mathrm{CCl}_{4}+12.5 \mathrm{mg} \\
\text { extract } / \mathrm{kg} \text { body wt }\end{array}$ & 1 week & Hepatocytes still distended \\
\hline 3. & $\begin{array}{l}\text { Feed }+\mathrm{CCl}_{4}+12.5 \mathrm{mg} \\
\text { extract } / \mathrm{kg} \text { body wt }\end{array}$ & 3 weeks & $\begin{array}{l}\text { Observable reversion towards normal liver } \\
\text { architecture }\end{array}$ \\
\hline 4. & $\begin{array}{l}\text { Feed }+\mathrm{CCl}_{4}+25.0 \mathrm{mg} \\
\text { extract } / \mathrm{kg} \text { body wt }\end{array}$ & 1 week & $\begin{array}{l}\text { Congestion of central vein and sinusoids. } \\
\text { No vascular degeneration }\end{array}$ \\
\hline 4. & $\begin{array}{l}\text { Feed }+\mathrm{CCl}_{4}+25.0 \mathrm{mg} \\
\text { extract } / \mathrm{kg} \text { body wt }\end{array}$ & 3 weeks & $\begin{array}{l}\text { Distention of hepatocytes with vacuolation } \\
\text { of their cytoplasm }\end{array}$ \\
\hline 5. & $\begin{array}{l}\text { Feed }+\mathrm{CCl}_{4}+37.5 \mathrm{mg} \\
\text { extract } / \mathrm{kg} \text { body wt }\end{array}$ & 1 week & Only slight improvement over Group 4 \\
\hline 5. & $\begin{array}{l}\text { Feed }+\mathrm{CCl}_{4}+37.5 \mathrm{mg} \\
\text { extract/kg body wt }\end{array}$ & 2 weeks & $\begin{array}{l}\text { Distortion of liver architecture. } \\
\text { Fragmentation of hepatocytes }\end{array}$ \\
\hline 5. & $\begin{array}{l}\text { Feed }+\mathrm{CCl}_{4}+37.5 \mathrm{mg} \\
\text { extract/kg body wt }\end{array}$ & 3 weeks & $\begin{array}{l}\text { Distended, fragmented and vacuolated } \\
\text { cytoplasm for hepatocytes. Congestion of } \\
\text { central vein and sinusoids persisted. }\end{array}$ \\
\hline
\end{tabular}

architecture shown by a section of liver of rat fed with normal diet with no treatment (Figure 1) became distorted by congestion of sinusoids, distended hepatocytes and degeneration of central nuclei, $24 \mathrm{hrs}$ after $\mathrm{CCl}_{4}$-treatment (Figure 2). Some recovery was observed in the liver architecture following administration of $12.5 \mathrm{mg} / \mathrm{kg}$ body weight of extract (Figure 3). At a higher concentration of the extract ( $37.5 \mathrm{mg} / \mathrm{kg}$ body weight), the liver architecture did not show improved recovery towards normal as expected. 


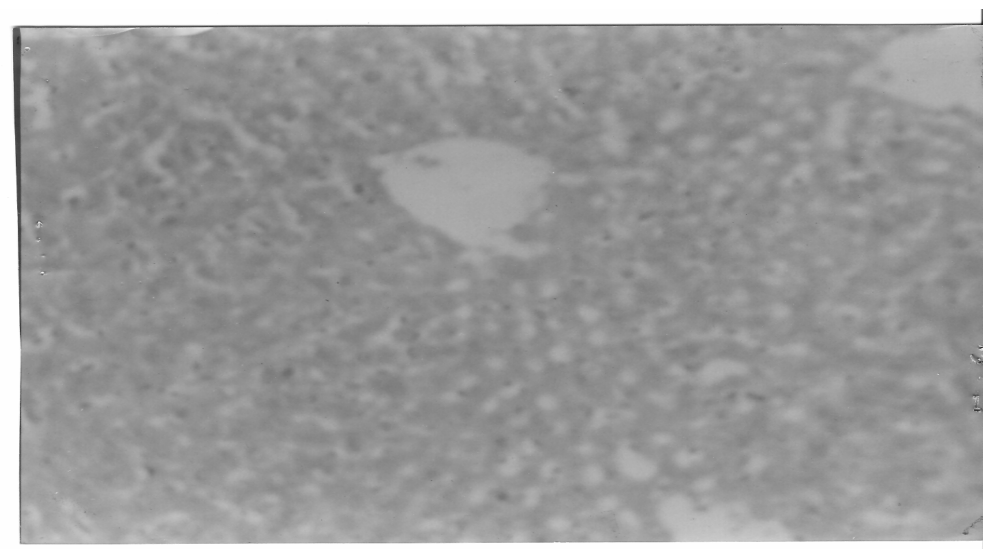

Figure 1: Section of liver of experimental animals fed with normal feed and water after 24 hrs, showing an essentially normal architecture.

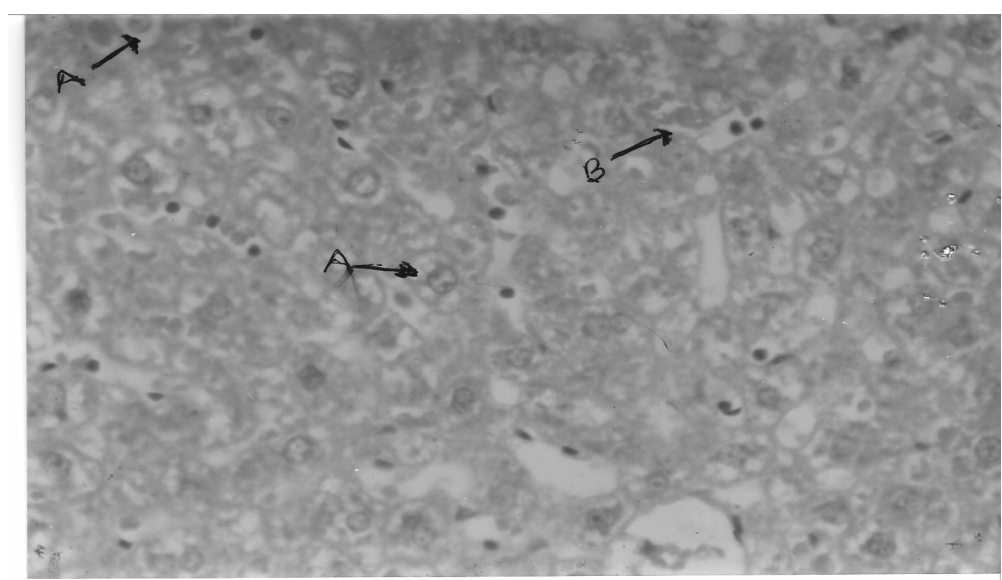

Figure 2: Section of liver of experimental animal $24 \mathrm{hrs}$ after treatment with $\mathrm{CCl}_{4}$, showing distorted architecture marked by congestion of sinusoids, distended hepatocytes and degeneration of central nuclei (A- distended hepatocyte with vacuolar degeneration, B- congested central vein).

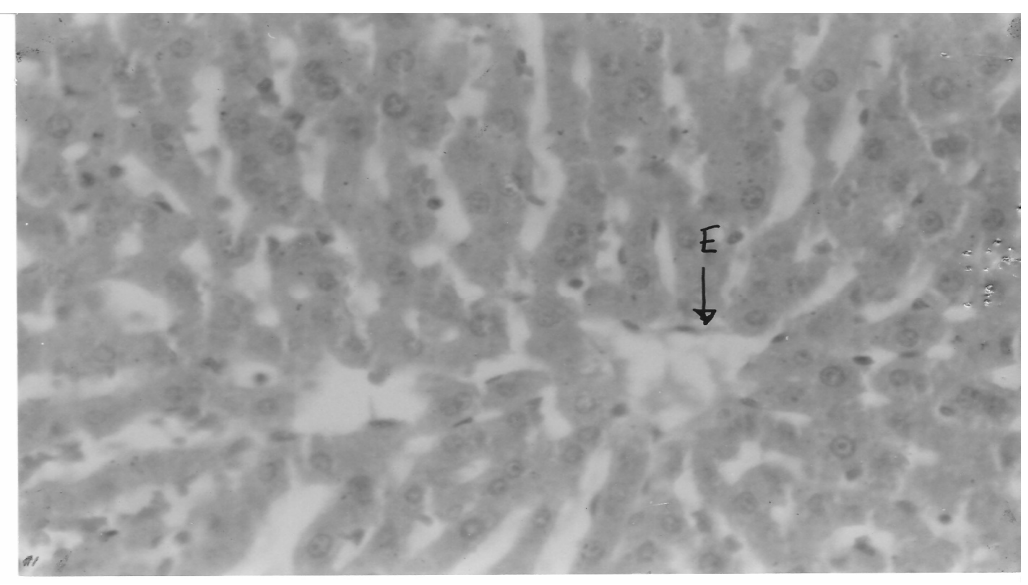

Figure 3: Section of liver of $\mathrm{CCl}_{4}$-treated experimental animal three weeks after administration of $12.5 \mathrm{mg} / \mathrm{kg}$ body weight of extract, showing observable improvement of architecture (undistended hepatocytes, no fatty degeneration; E marks the central vein). 


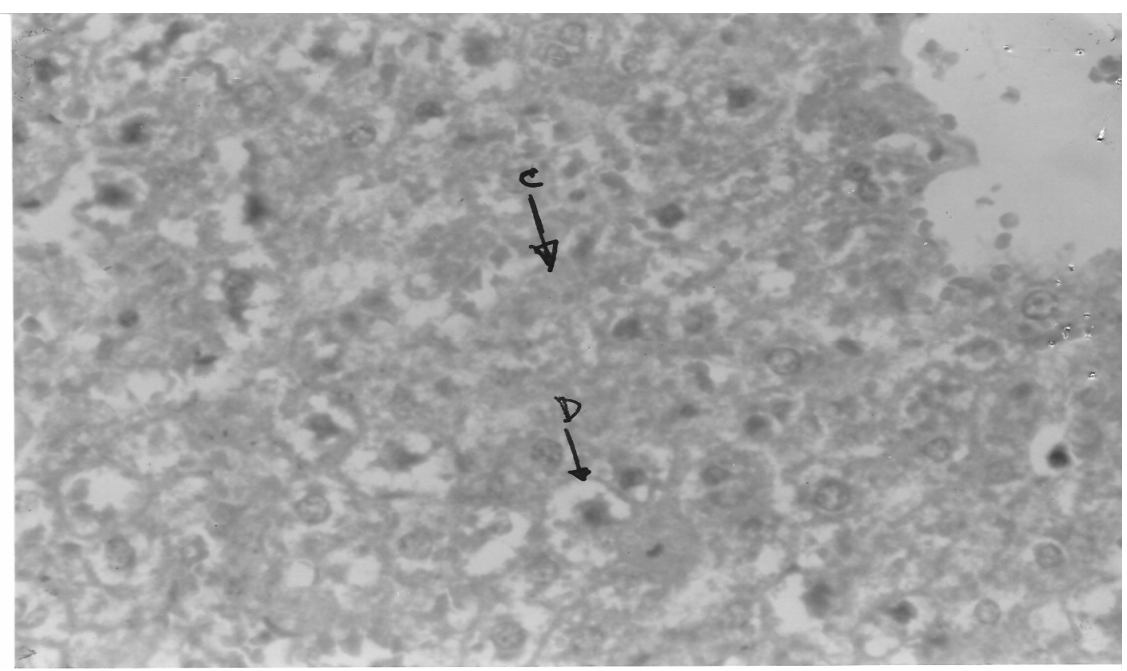

Figure 4: Section of liver of $\mathrm{CCl}_{4}$-treated experimental animal administered for two weeks with $37.5 \mathrm{mg} / \mathrm{kg}$ body weight of extract, showing fragmented cytoplasm. (C-area of liver necrosis, D-marking vacuolar degeneration).

\section{DISCUSSION}

The serum levels of aspartate and alanine amino transferase, and alkaline phosphatase determined in this study following administration of $\mathrm{CCl}_{4}$ were higher for group 2 than group 1 (control), indicating damage to the liver of the animals. This elevated levels remained so even after 21 days showing that $\mathrm{CCl}_{4}$ effected damage to the liver of the animals. It was observed that the administration of the extracts (at different concentrations) following $\mathrm{CCl}_{4}$ treatment produced reductions in the elevated levels of these enzymes, although a dose-dependent effect could not be established. Significant progressive reductions $(\mathrm{p}<0.05)$ were seen in rats administered with $12.5 \mathrm{mg} / \mathrm{kg}$ body weight of the extract. At $37.5 \mathrm{mg} / \mathrm{kg}$ body weight, the expected increased effect of the extract was not noted suggesting reduced 'efficacy' in restoring the damaged tissues and organs of the experimental animals.

The observable reduced effects seen for the extract at 25.0 and $37.5 \mathrm{mg} / \mathrm{kg}$ body weight in the recovery of the livers of the animals in groups 4 and 5 point to possible harmful effect of the $T$. bangwesis extract at these concentrations. In fact, there had been reports of serious harmful effects of ingestion of concentrated mistletoe extracts (Spiller et al., 1996; Alessi et al., 2003). It is notable that the results of the histological examination of the liver of the rats correlated with what was shown by the serum levels of the three enzymes determined.

The effects seen in this study were similar to earlier reports in which protective effects were noted for dried flower extract of Hibiscus sabdariffa L. (Obi et al., 2005 ) and ethanol extract of Ziziphus mauritiana leaf (Dahiru et al., 2005) administered to rats prior to $\mathrm{CCl}_{4}$-treatment. The response of the serum levels of the three enzymes studied in this report indicated that the extract had positive effect of producing some reversion in the $\mathrm{CCl}_{4}$-induced liver damage. The serum levels of theses enzymes are commonly used as biochemical markers of stress on the liver (Sturgill and Lambert, 1997).

The metabolism of $\mathrm{CCl}_{4}$ by cytochrome $\mathrm{P}_{450}$ to yield toxic trichloromethyl radicals had been suggested as a possible mechanism of the hepatotoxic effect of $\mathrm{CCl}_{4}$ (Kim et al., 2003). In addition, lipid peroxidation had also been implicated (Masuda and Nakamura, 1990). Oxidative damage to the liver through the action of activated oxygen species follows $\mathrm{CCl}_{4}$-administration (Farber and Gerson, 1984). While the protective effect reported for Z. mauritiana (Dahiru et al., 2005) had been attributed to probable interference with cytochrome $\mathrm{P}_{450}$. The present study where the 
$\mathrm{CCl}_{4}$-induced damage was significantly reversed by the aqueous extract of $T$. bangwesis suggests plausible involvement of the extract as a therapeutic agent for ameliorating liver damage. The possible mode of action of this effect could be discerned from the possible presence of high levels of phytochemicals with antioxidant properties as these have been known to be active ingredients in many herbs/shrubs with hepatoprotective effects (Wang et. al., 2007). It would be of interest to ascertain what effect the extract would have if administered prior to $\mathrm{CCl}_{4}$-administration, as this could provide information on possible hepatoprotective action of the plant extract. This would entail further investigations.

\section{REFERENCES}

Anand KK, Singh B, Chend D, Bhandan BK. 1992. An evaluation of Lawsonia alba extract as hepatoprotective agent. Planta Medic., 58: 22-25.

Antony S, Kutan R, Kuttan G. 1997. Effects of $V$. album in the inhibition of lung metastasis in mice induced by B16F10 melanoma cells. J. Exp. Clin. Cancer Res., 16: 159-162.

Baker FJ, Silverton RE. 1985. Introduction to Medical Laboratory Techniques, $\left(6^{\text {th }}\right.$ edn). Butterworths: London; 320-330.

Dahiru D, William ET, Nadro MS. 2005. Protective effect of Zizipus mauritana leaf extract on carbon tetrachlorideinduced liver injury. African J. Biotech., 4(10): 1177-1179.

Ekeke G I, Shode FO. 1990. Phenylalanine is the predominant antisickling agent in Cajanus cajan seed extract. Planta Medica, 56: 41-43.

El-Said F, Fadulu SO, Kuye JO, Sofowora EA. 1971. Antimicrobial property of the buffered extracts of Fagara chewing stick. Lloydia, 34: 171.

Elekwa I, Monanu MO, Anosike EO. 2005. Effects of aqueous extracts of Zanthoxylum macrophylla roots on membrane stability of human erythrocytes of different genotypes. Biokemistri., 17(1): 7-12.

Farber JL, Gerson RT. 1984. Mechanism of cell injury of Hepatotoxic chemicals. Pharmacological Reviews, 36: 71-75.
Gupta SS. 1994. Prospects and perspectives of natural plant products in medicine. Indian J. Pharmacol., 26: 1-12.

Haussament TU. 1977. Quantitative determination of serum alkaline phosphatase. Clin. Chem. Acta, 35: 271273.

Ibekwe SE, Uwakwe AA, Monanu MO. 2007. In vivo effects of sodium benzoate on plasma aspartate amino transferase and alkaline phosphatase of wistar albino rats. Scientific Res. \& Essay, 2(1): 010-012.

Kim SH, Yang YP, Sung SH, Kim CJ, Kim JW, Kim YC. 2003. Hepatoprotective dibenzylbutyrolactone ligans ofTorreya nucifera against $\mathrm{CCl}_{4}$-induced toxicity in primary cultured rat hepatocytes. Biol. Pharm. Bull., 26(8): 1202-1205.

Masuda Y, Nakamura Y. 1990. Effect of oxygen deficiency and calcium omission on $\mathrm{CCl}_{4}$ in isolated perfused livers from pentobarbital pretreated rats. Biochem. Pharm., 40: 1865-1876.

Michel A. 2002. Tree, Shrub and Liana of West African Zones. Margaf Publishers GMBH, Paris. p. 440.

Obatomi R, David R, Ewenodere O, Bikomo V, Temple J. 1994. Antidiabetic properties of the African mistletoe in streptozotocin-induced diabetic rats. $J$. Ethno. Pharmacology., 43(1): 13-17.

Obi FO, Chiazo OC, Ezeani NF, Omorodion OS, Fakoya JB. 2005. Protective effects of dried flower extract of Hibiscus sabdariffa $L$. on carbon tetrachlorideinduced liver injury in the rat. Global J. Pure \& Appld. Sci., 11(2): 249-251.

Onofeghara FA. 1971. Studies on the development of Tapinanthus bangwesis (Engler \& K. Trause) Danser. Ann. Bot., 35: 729-743.

Rao KS, Mishra SH. 1998. Anti-inflammatory and Hepatoprotective activities of fruits of Moringa ptergosperma gaertn. Indian J. Natural Prod., 14: 3.

Sofowara EA, Isaacs-Sodeye W.A. 1971. Reversal of sickling and crenation in erythrocytes by the root extract of Fagara zanthoxyloides. Biochemistry, 10: 26172624.

Sofowara EA. 1975. Isolation and characterization of an anti-sickling agent from Fagara zanthoxyloides. Lloydia, 38: 169-171. 
Stein G, Berg P. 1998. Modulation of cellular and hormonal immune responses during exposure of healthy individuals to an aqueous mistletoe extract. Eur. J. Med. Res., 3: 307-314

Sturgill MG, Lambart GH. 1997. Xenobioticinduced hepatoxicity: Mechanisms of liver injury and methods of monitoring hepatic function. Clin. Chem., 43: 15121526.

Vehmeyer K, Hajto T, Hostanska K. 1998. Lecithin-induced increase in cologenic growth of haematopoietic progenitor cells. Eur. J. Haematology, 60: 16-20.
Wang CJ, Wang JM, Lin WL, Chu Y, Chau FP, Tseng TH. 2000. Protective effect of Hibiscus anthocyanins against ter-butylhydroperoxide-induced hepatic toxicity in rats. Food Chem. Toxicol., 38: 411-6.

Wang R, Kay J, Wang D, Lien LL, Lien EJ. 2007. A survey of Chinese herbal ingredients with liver protection activities. Clin. Med., 2: 5.

WHO. 1993. Research guidelines for Evaluating the Safety and Efficacy of Herbal Medicines. Regional Office for Western Pacific: Manilla. 